\title{
EVALUATION AND COMPARISON OF DNA EXTRACTION KITS FOR THE DETECTION OF Clostridium difficile IN SPIKED AND FIELD FAECES FROM PIGLETS BY USING REAL-TIME PCR
}

\author{
Jana Avberšek*, Urška Zajc, Igor Gruntar, Brane Krt, Matjaž Ocepek \\ Veterinary Faculty, University of Ljubljana, Gerbičeva 60, 1000 Ljubljana, Slovenia \\ *Corresponding author, E-mail: jana.avbersek@vf.uni-lj.si
}

\begin{abstract}
In complex samples (faeces, soil, food, etc.), Clostridium difficile is often present in the form of dormant spores that cause reduced effectiveness of DNA extraction. With the aim of determining an optimal DNA extraction procedure from spores, DNA extraction from faecal samples spiked with a known number of $C$. difficile spores and faecal samples from piglets was performed with three manual protocols, using two commercial kits and subsequent real-time PCR (rtPCR) DNA amplification. DNA extraction protocols, including mechanical disruption by bead beating, gave better results with rtPCR. The SmartHelix DNAid Complex Kit proved to be more efficient than the QIAamp DNA Stool Mini Kit, suggesting that an optimal combination of mechanical, enzymatic, and chemical lysis seems to be required for the best results.
\end{abstract}

Key words: Clostridium difficile; DNA extraction; real-time PCR; piglets; faeces; spores

\section{Introduction}

Clostridium difficile infection is one of the most common causes of nosocomial diarrhoea. Subclinical colonisation has been described in humans and in several animal species, which seem to be a significant reservoir of $C$. difficile and a potential source of bacteria for communityacquired $C$. difficile-associated disease $(1,2)$. The detection of low numbers of $C$. difficile in samples (e.g. food, environmental samples, and asymptomatic humans and animals) is extremely important, as an exact infectious dose

Received:8December 2016

Accepted for publication: 7 March 2017 is not completely known, but remains a challenge. Enrichment culture is the preferred 'gold standard' method for the isolation of C. difficile, but is timeconsuming and labour intensive, although it provides an isolate for further studies (3). Realtime PCR (rtPCR) could potentially serve as a rapid screening test, but culture-positive/rtPCR negative samples represent a drawback to this method. It could be improved by an enrichment step prior rtPCR or with a better DNA extraction method $(4,5)$. A resistant spore coat is difficult to lyse; therefore, the release of nucleic acid is limited and consequently reduces the effectiveness of C. difficile DNA extraction methods. In this case, a mechanical disruption method is required. Beadbeating has been shown to be one of the most 
effective techniques for DNA extraction from soil samples and from Bacillus sp. spores $(6,7)$. Freifeld et al. (8) described a novel lysis microreactor with heat, and chemical and physical (shear flow) disruption, followed by PCR, for a rapid diagnosis of $C$. difficile. In our study, we attempted to develop an optimal DNA extraction method from the faeces of piglets without diarrhoea in order to improve the sensitivity of the rtPCR for the detection of C. difficile.

\section{Materials and methods}

For the spore preparation, C. difficile (strain $51377, \mathrm{~A}+\mathrm{B}+\mathrm{CDT}+)$ was plated onto $5 \%$ sheep blood agar (Columbia blood agar base; Oxoid, United Kingdom) (anaerobically, $37^{\circ} \mathrm{C}$, five days) and the spores were purified using HistoDenz (Sigma-Aldrich, USA), based on a previously published protocol (9). The spores were stored in sterile distilled water at $4{ }^{\circ} \mathrm{C}$. Ten-fold dilutions $\left(10^{-1}\right.$ to $10^{-6}$ dilutions) of purified spores were prepared. The number of spores was estimated using dark-field microscopy and colony count on blood agar.

To evaluate the content of free $C$. difficile DNA in the experimental spore suspension, the $10^{-1}$ dilution was filtered $(0.45 \mu \mathrm{m}$; Macherey-Nagel, Germany) to remove spores. The filtrate was used as a DNA source and amplified nine times with each rtPCR as described further in the text. Comparably, the unfiltered spore suspension (dilution $10^{-1}$ ) was also amplified with rtPCR.

Dilutions of purified spores $(100 \mu l)$ were used for spiking C. difficile - negative (rtPCR and enrichment culture negative) faecal specimens (1 g) to reach the spore concentrations presented in Table 1. Three sets of individually spiked faeces were prepared for DNA extraction in order to enable testing in triplicate. DNA was extracted using three extraction protocols (in triplicate with two negative controls). Protocol A was QIAamp DNA Stool Mini Kit (Qiagen, Germany) (QS) used according to the manufacturer's protocol. Meanwhile, for protocol B (QSB) the same kit was used, but mechanical disruption was performed before incubation at $95{ }^{\circ} \mathrm{C}$. Samples were mixed with $400 \mu \mathrm{L}$ of ASL buffer (from the kit) and 370 $\mathrm{mg} \leq 106 \mu \mathrm{m}$ of glass beads (Sigma-Aldrich, USA), followed by bead beating (6400 rpm for $90 \mathrm{~s}$ ) on a MagNA Lyser instrument (Roche Diagnostics,
Germany). The samples were then centrifuged at $20000 \times g$ for $3 \mathrm{~min}$. Supernatants were transferred to new tubes and mixed with $1000 \mu \mathrm{L}$ of ASL buffer. Samples were afterwards incubated at $95^{\circ} \mathrm{C}$ for $5 \mathrm{~min}$ and further processed according to the manufacturer's protocol. In protocol $\mathrm{C}$, we used a SmartHelix DNAid Complex Kit (ExVivon, Slovenia) (SH), intended for extraction of bacterial DNA from complex samples or from bacteria with hard cell walls. The name and manufacturer of this commercial extraction kit were changed after the study, and it is now known as DNA Isolation from Complex Samples (Institute of Metagenomics and Microbial Technologies, Slovenia, info@immt.eu). DNA extraction was carried out according to the manufacturer's instructions. MagNA Lyser instrument (Roche Diagnostics, Germany) was used for bead beating, three times at $6400 \mathrm{rpm}$ for $45 \mathrm{~s}$.

The efficiency of DNA extraction from spores was tested with two real-time PCR assays: TaqMan real-time PCR (TMrtPCR) and LightCycler realtime PCR (LC rtPCR) $(5,10)$. Toxin gene $t c d B$ was amplified with and without internal control three times.

All DNA extraction procedures were also tested on rectal swabs from apparently healthy piglets without diarrhoea ( $<10$ days old; $n=40$ ) collected from a large farm. Samples were taken in duplicate. One rectal swab per animal was washed in $1 \mathrm{~mL}$ sterile distilled water and $200 \mu \mathrm{L}$ was used for each of the three tested DNA extraction protocols described above. Toxin gene $t c d B$ was amplified with both rtPCR assays with and without internal control. The remaining rectal swab was used for bacteriological cultivation using a selective enrichment cultures (5).

\section{Results}

A comparison of spores counted under a microscope $\left(10^{6}\right.$ spores $\mathrm{mL}^{-1}$ in stock solution) and the colony count approach $\left(4 \times 10^{5}\right.$ spores $\mathrm{mL}^{-1}$ in stock solution) gave comparable results.

The detected level of free $C$. difficile DNA in filtered suspension (dilution $10^{-1}$ ) was close to the rtPCR detection limit: in nine reactions performed per each PCR type, only one LC rtPCR and one TMrtPCR were positive with threshold cycle (Ct) values $\geq 40$. In comparison, the unfiltered spore suspension without DNA extraction was rtPCR positive with Ct values $\geq 40$, while samples spiked 
Table 1: Molecular detection of Clostridium difficile tcdB gene in faecal samples spiked with spores

\begin{tabular}{|c|c|c|c|c|c|c|c|c|c|c|c|c|c|}
\hline \multirow{2}{*}{$\begin{array}{l}\text { DNA extraction } \\
\text { protocol }\end{array}$} & $\begin{array}{c}\text { number of } C \text {. difficile } \\
\text { spores } \mathrm{g}^{-1} \text { of faeces }\end{array}$ & $10^{4}$ & $10^{3}$ & \multicolumn{3}{|c|}{$10^{2}$} & \multicolumn{3}{|c|}{$10^{1}$} & \multicolumn{3}{|c|}{1} & 0 \\
\hline & samples & E $1-3^{b}$ & E 1-3 & \multicolumn{3}{|c|}{ E 1-3 } & \multicolumn{3}{|c|}{ E 1-3 } & \multicolumn{3}{|c|}{ E 1-3 } & E $1-3$ \\
\hline \multirow{3}{*}{$\begin{array}{l}\text { QIAamp DNA } \\
\text { Stool Mini Kit }\end{array}$} & $\mathrm{LC} / \mathrm{TM}^{\mathrm{a}} 1$ & \multirow{3}{*}{$\operatorname{pos}^{c}$} & \multirow{3}{*}{ pos } & pos & negd $^{d}$ & pos & neg & \multirow{3}{*}{ neg } & \multirow{3}{*}{ neg } & \multirow{3}{*}{\multicolumn{3}{|c|}{ neg }} & \multirow{3}{*}{ neg } \\
\hline & LC/TM 2 & & & neg & $++^{e} /-^{f}$ & neg & neg & & & & & & \\
\hline & LC/TM 3 & & & $-1+$ & $-/+$ & pos & $-/+$ & & & & & & \\
\hline \multirow{3}{*}{$\begin{array}{l}\text { QIAamp DNA } \\
\text { Stool Mini Kit } \\
\text { with bead } \\
\text { beating }\end{array}$} & $\mathrm{LC} / \mathrm{TM} 1$ & \multirow{3}{*}{ pos } & \multirow{3}{*}{ pos } & pos & $-/+$ & neg & neg & \multirow{3}{*}{ neg } & \multirow{3}{*}{ neg } & \multirow{3}{*}{\multicolumn{3}{|c|}{ neg }} & \multirow{3}{*}{ neg } \\
\hline & $\mathrm{LC} / \mathrm{TM} 2$ & & & $-/+$ & neg & $\begin{array}{c}\text { neg } \\
1\end{array}$ & $-/+$ & & & & & & \\
\hline & LC/TM 3 & & & pos & neg & $-/+$ & $-/+$ & & & & & & \\
\hline \multirow{3}{*}{$\begin{array}{c}\text { SmartHelix } \\
\text { DNAid } \\
\text { Complex Kit }\end{array}$} & LC/TM 1 & \multirow{3}{*}{ pos } & \multirow{3}{*}{ pos } & \multirow{3}{*}{\multicolumn{3}{|c|}{ pos }} & \multirow{3}{*}{ pos } & neg & $+/-$ & \multirow{3}{*}{ neg } & \multirow{3}{*}{ pos } & \multirow{3}{*}{ neg } & \multirow{3}{*}{ neg } \\
\hline & LC/TM 2 & & & & & & & neg & neg & & & & \\
\hline & LC/TM 3 & & & & & & & $+/-$ & neg & & & & \\
\hline \multicolumn{14}{|c|}{$\begin{array}{l}\text { a LC/TM, LightCycler real-time PCR/TaqMan real-time PCR res } \\
\text { b E 1-3, DNA extraction triplicates } \\
{ }^{c} \text { pos, positive LightCycler and TaqMan real-time PCR result } \\
\text { d neg, negative LightCycler and TaqMan real-time PCR result } \\
\text { e }+ \text {, positive real-time PCR result (Ct value }>40 \text { ) } \\
\text { f-, negative real-time PCR result }\end{array}$} \\
\hline
\end{tabular}

Table 2: Comparison of different DNA extraction protocols/kits used for molecular detection of Clostridium difficile tcdB gene in animal samples compared with culture results $(n=40)$

\begin{tabular}{|c|c|c|c|c|c|c|c|c|c|c|c|c|c|}
\hline & & \multicolumn{2}{|c|}{$\mathrm{LC}^{\mathrm{a}}-\mathrm{QS}^{\mathrm{c}}$} & \multicolumn{2}{|c|}{ LC-QSB ${ }^{\mathrm{d}}$} & \multicolumn{2}{|c|}{ LC-SH ${ }^{e}$} & \multicolumn{2}{|c|}{$\mathrm{TM}^{\mathrm{b}}-\mathrm{QS}$} & \multicolumn{2}{|c|}{ TM-QSB } & \multicolumn{2}{|c|}{ TM-SH } \\
\hline & & $\operatorname{pos}^{f}$ & nege & pos & neg & pos & neg & pos & neg & pos & neg & pos & neg \\
\hline culture pos & 29 & 11 & 18 & 14 & 15 & 25 & 4 & 10 & 19 & 15 & 14 & 27 & 2 \\
\hline culture neg & 11 & 6 & 5 & 8 & 3 & 11 & 0 & 7 & 4 & 7 & 4 & 11 & 0 \\
\hline total & 40 & 17 & 23 & 22 & 18 & 36 & 4 & 17 & 23 & 22 & 18 & 38 & 2 \\
\hline
\end{tabular}

${ }^{\text {a }}$ LC, LightCycler real-time PCR

b TM, TaqMan real-time PCR

c QS, QIAamp DNA Stool Mini Kit

d QSB, QIAamp DNA Stool Mini Kit with bead beating

e SH, SmartHelix DNAid Complex Kit

${ }^{\mathrm{f}}$ pos, positive result (samples with sigmoid curve)

${ }^{\mathrm{g}}$ neg, negative result

with the $10^{-1}$ spore dilution presented Ct values between 28.28 and 33.70 after DNA extraction with different DNA extraction protocols/kits.

When the SH extraction method was used, the rtPCR results for spiked samples showed better efficiency/sensitivity, since the sample with one C. difficile spore $\mathrm{g}^{-1}$ of faeces was rtPCR positive, while the QS and QSB samples were positive at 10-100 spores $\mathrm{g}^{-1}$ of faeces (Table 1). Similarly, a ten-fold difference was observed for $100 \%$ probability of detection (Table 1). Positive samples spiked with 100 and 10 spores $g^{-1}$ of faeces that were positive only with one rtPCR assay (in Table 1 indicated as $-/+$ or $+/-$ ) had Ct value $>40$, which suggested that the samples were near the limit of detection of the assays. Inhibition of rtPCR was not observed.

Comparison of three DNA extraction protocols on rectal swabs proves that $\mathrm{SH}$ yielded the highest number of rtPCR positive samples, followed by QSB and QS (Table 2). The Ct values for $\mathrm{SH}$ samples were on average 6-8 cycles lower in comparison to the QSB samples and 8-12 cycles lower than the QS samples (data not shown). Furthermore, 38 
$(95 \%)$ samples were rtPCR positive. Among these samples, 13 (34.2\%) were positive when DNA was extracted with $\mathrm{SH}$, but negative with other protocols. In 8 (21.1\%) samples, the LC rtPCR and TMrtPCR results were not the same; two samples were positive with TMrtPCR only when $\mathrm{SH}$ was used, and in 6 samples (4 QS and 2 QSB samples) either LC rtPCR or TMrtPCR was positive. In all samples with different LC rtPCR/TMrtPCR results, the $\mathrm{Ct}$ values for positive rtPCR samples were higher than 40 and reproducibility was not $100 \%$.

\section{Discussion}

The sensitivity of the rtPCR assays also depends upon high DNA yield and purity, which may be achieved with an optimal DNA extraction method. The efficient lysis of the clostridial spores and removal of PCR inhibitors are the major challenges to improve DNA extraction from complex samples (e.g. faeces, soil, food). Faecal samples with a known number of $C$. difficile spores were prepared and subjected to three DNA extraction protocols, followed by rtPCR. The possibility of false positive results due to free $C$. difficile DNA in samples was ruled out via a filtered spore suspension experiment, where the rtPCR results demonstrated very low amounts of free $C$. difficile DNA in spore suspensions, well under the limit of detection in the more diluted samples. Therefore, the rtPCR results obtained in experiments comparing different DNA extraction kits were most likely due to efficient DNA extraction from spores and not due to the presence of free DNA in samples.

The results of spore quantification differed slightly between the two applied methods. A lower number of $C$. difficile in stock solution was detected when the colony-forming unit (CFU) approach was used (5.6 $\log 10$ vs. $6 \log 10)$. In our study, blood agar was used, which is not supplemented with taurocholate to support the germination of spores; therefore, the number of CFU would probably be higher using a supplemented medium (11).

The evaluation of three DNA extraction protocols for spiked and field samples showed that $\mathrm{SH}$ provided the greatest DNA yield for the detection of $C$. difficile with rtPCR. However, the testing of spiked QS and QSB samples revealed no difference between these two extraction protocols, while QSB results were better when testing field samples (22 QSB positive in contrast to $17 \mathrm{QS}$ positive samples). A possible explanation for this could be that the beads used in QSB extraction could also improve the lysis of a cell wall of vegetative bacteria in swabs.

A limitation of this study is the fact that only two commercial kits were compared. QS has been widely used in our laboratory for DNA extraction from faecal samples; in order to improve the sensitivity of $C$. difficile rtPCR assays, bead-beating was introduced prior to QS protocol. Furthermore, $\mathrm{SH}$ was found to be effective for Mycobacterium avium subsp. paratuberculosis (Map) DNA extraction from faecal samples from sub-clinically Map-infected shedders (12). As Map possesses a complex, resistant, lipid-rich cell wall, which is also difficult to lyse during DNA extraction, we surmised that $\mathrm{SH}$ could contribute to the efficiency of DNA extraction from $C$. difficile spores in complex samples, especially in samples with a low number of bacteria (e.g. animal shedders).

In this study, all the samples were amplified with LC rtPCR and TMrtPCR. Among 40 field samples, LC rtPCR and TMrtPCR results differed in 8 of them, but in the entire lot Ct values were higher than 40, indicating a small number of C. difficile organisms in the sample, probably close to the limit of detection of the rtPCR assays used.

To the best of our knowledge, only two studies dealing with the comparison of culture and inhouse rtPCR assays for the detection of $C$. difficile in animal samples have been published $(4,5)$. Both studies reported $7-11 \%$ culture-positive/ rtPCR-negative and 11\% culture-negative/rtPCR positive-samples. The differences between culture and rtPCR results could be connected with samples (especially rectal swabs), because faeces are never a homogeneous medium, and the concentration of bacteria may vary. In our study, culture-positive/ rtPCR-negative samples were reduced to $5 \%$ when the SH kit was used. Furthermore, the percentage of culture negative/rtPCR positive samples was in agreement with previously published studies for QS samples (15-17.5\%), while improvement was observed using QSB (17.5-20\%) and SH (27.5\%) protocols, showing that the application of a better DNA extraction procedure, including beadbeating, increases the number of positive rtPCR samples.

Both SH and QS have similar processing times and are based on silica membrane spin columns, but QS is considerably more expensive than $\mathrm{SH}$ is. Superior $\mathrm{SH}$ results indicate that an optimal 
extraction procedure should combine mechanical and enzymatic/chemical lysis. Moreover, QSB and $\mathrm{SH}$ comprise glass beads for mechanical disruption, while zirconia/silica beads could also be efficient for destroying spores and highly resistant cell walls $(6,13)$.

In conclusion, the selection of an optimal DNA extraction method implicating mechanical disruption could significantly improve the detection of $C$. difficile.

\section{Acknowledgments}

This work was supported by the Slovenian Research Agency (grant no. P4-0092 and grant for young researchers - J. Avbersek).

\section{References}

1. Hensgens MPM, Keesen EC, Squire MM, et al. Clostridium difficile infection in community: a zoonotic disease? Clin Microbiol Infect 2012; 18: $635-45$.

2. Banks A, Brown DJ, Mather H, Coia JE, Wiuff C. Sentinel community Clostridium difficile infection (CDI) surveillance in Scotland, April 2013 to March 2014. Anaerobe 2016; 37: 49-53.

3. Crobach MJT, Dekkers OM, Wilcox MH, Kuijper EJ. European society of clinical microbiology and infectious diseases (ESCMID): data review and recommendations for diagnosing Clostridium difficile-infection (CDI). Clin Microbiol Infect 2009; 15: 1053-66.

4. Houser BA, Hattel AL, Jayarao BM. Real-time multiplex polymerase chain reaction assay for rapid detection of Clostridium difficile toxin-encoding strains. Foodborne Pathog Dis 2010; 7: 719-26.

5. Avbersek J, Cotman M, Ocepek M. Detection of Clostridium difficile in animals: comparison of real-time PCR assays with the culture method. J Med Microbiol 2011; 60: 1119-25.
6. Miller DN, Bryant JE, Madsen EL, Ghiorse WC. Evaluation and optimization of DNA extraction and purification procedures for soil and sediment samples. Appl Environ Microbiol 1999; 65: 4715-24.

7. Dauphin LA, Moser BD, Bowen MD. Evaluation of five commercial nucleic acid extraction kits for their ability to inactivate Bacillus anthracis spores and comparison of DNA yields from spores and spiked environmental samples. J Microbiol Methods 2009; 76: 30-7.

8. Freifeld AG, Simonsen KA, Booth CS, et al. A new rapid method for Clostridium difficile DNA extraction and detection in stool. J Mol Diagn 2012; 14: 274-9.

9. Sorg JA, Dineen SS. Laboratory maintenance of Clostridium difficile. Curr Protoc Microbiol 2009; 12: 9A.1.1-10.

10. Avbersek J, Zajc U, Micunovic J, Ocepek M. Improved detection of Clostridium difficile in animals by using enrichment culture followed by LightCycler real-time PCR. Vet Microbiol 2013; 64: 93-100.

11. Burns DA, Minton NP. Sporulation studies in Clostridium difficile. J Microbiol Methods 2011; 87: 133-8.

12. Logar K, Kopinc R, Bandelj P, Lapanje A, Ocepek M. Evaluation of combined high-efficiency DNA extraction and real-time PCR for detection of Mycobacterium avium subsp. paratuberculosis in subclinically infected dairy cattle: comparison with faecal culture, milk real-time PCR and milk ELISA. BMC Vet Res 2012; 8: e49 (10 pp.) https: / / bmcvetres.biomedcentral.com/articles/10.1186/1746-6148-8-49 (Dec. 2016)

13. Kim BH, Ramanan R, Cho DH, et al. Simple, rapid and cost-effective method for high quality nucleic acids extraction from different strains of Botryococcus braunii. PLoS ONE 2012; 7: e37770 $(90$ pp.) http://journals.plos.org/plosone/article?id=10.1371/journal.pone.0037770 (Dec. 2016) 


\title{
OVREDNOTENJE IN PRIMERJAVA KOMERCIALNIH KOMPLETOV ZA IZOLACIJO DNK ZA DOKAZOVANJE BAKTERIJE Clostridium difficile V BLATU PRAŠIČKOV Z METODO PCR V REALNEM ČASU
}

\author{
J. Avberšek, U. Zajc, I. Gruntar, B. Krt, M. Ocepek
}

Povzetek: V kompleksnih vzorcih (blato živali, zemlja, hrana, itd.) je bakterija Clostridium difficile pogosto prisotna v obliki spor, ki so vzrok za slabšo učinkovitost izolacije DNK. Da bi določili optimalni postopek izolacije DNK iz spor, smo s tremi različnimi protokoli in uporabo dveh komercialnih kompletov za izolacijo DNK izolirali DNK iz vzorcev blata z znanim številom C. difficile spor in vzorcev blata prašičkov. DNK smo pomnoževali z metodo PCR v realnem času (rtPCR). Boljše rtPCR rezultate smo dobili pri vzorcih, kjer smo pri izolaciji DNK uporabili tudi mehansko razbitje celic s kroglicami. SmartHelix DNAid Complex Kit je bil učinkovitejši komercialni kompletkot QIAamp DNA Stool Mini Kit, kar nakazuje na optimalno kombinacijo mehanske, encimske in kemične lize za najboljši izplen DNK.

Ključne besede: Clostridium difficile; izolacija DNK; spore; PCRv realnem času; prašički; blato 